Manuscript received: 01.04.2021

Accepted: 09.06.2021

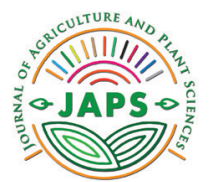

In print: ISSN $2545-4447$

On line: ISSN 2545-4455

https://doi.org/10.46763/JAPS211910024s

Original scientific paper

\title{
QUALITATIVE FEATURES OF OATS GROWN IN CONDITION OF ORGANIC PRODUCTION
}

\author{
Dragica Spasova ${ }^{1 *}$, Darina Valcheva ${ }^{2}$, Biljana Atanasova ${ }^{1}$, Adrijana Burovska ${ }^{1}$, Dusan Spasov', \\ Mite Ilievski ${ }^{1}$ \\ ${ }^{'}$ Faculty of Agriculture, Goce Delcev University - Stip, Krste Misirkov 10-A, 2000 Stip, Republic of North Macedonia \\ ${ }^{2}$ Institute of Agriculture, 8400 Karnobat, Republic of Bulgaria \\ *Corresponding author: dragica.spasova@ugd.edu.mk
}

\begin{abstract}
The research was conducted in 2015 and 2016, at 11 oats genotypes in terms of organic production. Three of the studied genotypes were domestic populations: Krivogashtani, Trebenishta and Kuchevishte. The rest were introduced varieties, including Rajac, Slavuj and Lovken from Serbia and Kupa, Baranja, Eksplorer, Shampionka and Istra from Croatia.

On average, for both years, the variety Shampionka had the highest protein content (14.80\%), which indicates that the grain has a high nutritional value. There is a statistically significant difference between the examined genotypes. The percentage of fat in oats, grown organically, in both years of research is statistically different at different genotypes. On average, in both years of research, the fat content ranged from $2.31 \%$ in the populationTrebenishta, up to $4.47 \%$ in the population of Krivogashtani. The variety Baranja is with the highest ash content in the grains $(4,35 \%)$ in average, for the period of research. In the same group a, is ranked variety Shampionka, with $4.30 \%$. Between genotypes there is a statistically significant difference. For the period 20152016, all examined genotypes belong to group a, that is, all varieties and populations contain high cellulose content. Given that the property cellulose content is negatively correlated with the quality of oats, in plant selection, varieties with lower cellulose content are more important. Analysis of variance for the quality of oats grain shows that the content of protein, fat and ash values are relatively constant in the years of the research. The conditions in the years of research had a weaker effect than the genotype. The strength of the genotype is $65.06 \%, 67.06 \%$ and $72.04 \%$, respectively. The properties content of protein, fat and ash are strongly influenced by the genotype while the cellulose content is strongly influenced by the year.
\end{abstract}

Keywords: variety, population, proteins, fats, ash, cellulose

\section{INTRODUCTION}

Oat (Avena sativa L.) is one of the oldest cereal crops grown as a stand-alone crop due to its high commercial qualities. It has a high protein content, with balanced amino acid composition (Moudry,1992; Nikolic et al., 1989; Спасова, 2008), unlike other cereals, a favorable relationship between nutritional properties and high digestibility, which make oats an indispensable concentrated fodder in the diet of domestic animals.

The agricultural relevance of oats is due to the quality of the grain and the low demands on cultivation conditions, so it can work well in areas where other cereals produce low yields (Spasojevic et al., 1984). With the development of the food industry and the growing need for healthy and dietary foods, the importance of oats for people's balanced nutrition has increased. The oats breeding tends towards the creation of higher yielding varieties, but also requires some irreplaceable grain properties in relation to the production of valuable food and nutritional products (Савова, 2007; Георгиев et al., 2003).

Oat grain has features not found in other cereals. These include: high fat content, proteins 
with balanced amino acid content (Moudry, 1992, Yeoh and Watson, 1981; Frey and Colville, 1986), fibers with high content of beta gluten (Wood, 1986; Sterbia and Moudry, 2001).

Grain is high in quality protein and therefore in the food industry a range of easily digestible products of high nutritional value, such as oat flakes, semolina, oat flour is produced from the oat grains (Antonova et al. 2000).

Many authors examine the content of these valuable constituents in the oat grain and conclude that the content varies with the variety and conditions of crop cultivation (Saastomoinen et al., 2004; Yeoh and Watson, 1981; Sterbia and Mourdy, 2001).
Oats are one of the most suitable cereals for organic production (Spasojevic et al., 1984). This is consistent with studies of other authors (Lockeretz et l., 1981) that examining varieties of oats in terms of organic production, discovered that oats is very suitable cereal for organic production, considering the high yields they have received, which ranged from 4 to $5 \mathrm{t} / \mathrm{ha}$.

The aim of our research was examining the chemical properties of oat grain in terms of organic production, which would allow to determine the importance of varieties in human nutrition and their recommendation in modern culinary and food technology.

\section{MATERIAL AND METHODS}

Field trials were set up on the experimental field of Faculty of Agriculture, University "Goce Delchev", in Strumica, during 2015 and 2016, and laboratory examinations were performed in the laboratories of the Faculty of Agriculture.

Eleven oat genotypes were analyzed. Three of the populations were domestic:Krivogashtani, Trebenishta and Kuchevishte. The rest introduced varieties were from abroad, including Rajac, Slavuj and Lovken from Serbia and varieties: Kupa, Baranja, Eksplorer, Shampionka and Istra from Croatia.

The experiments were set up in three repetitions, arranged by the random block system method, with its basic parcel of $5 \mathrm{~m}^{2}$.

The distance between the variants was 0,50 $\mathrm{m}$, and between repetitions $1 \mathrm{~m}$. The distance between rows was $20 \mathrm{~cm}$. Seed rate of 550 grains per $1 \mathrm{~m}^{2}$ was used. Basic soil tillage was performed at a depth of $35 \mathrm{~cm}$. Prior to sowing, additional processing and fertilization with 30 $\mathrm{t} /$ ha biofertilizer was performed, in accordance with the organic production regulations.
Prior to harvest, $1 \mathrm{~m}^{2}$ material was taken from each plot for laboratory analysis, to analyze the chemical properties of oat grains that determine grain quality. The chemical properties of the grain were determined by the following methods:

- Cellulose: Intermediate Filtration Method (ISO 6865: 2000). Animal feed Determination of raw fiber content;

- Protein:Cerealsandlegumes-Determination of nitrogen content and calculation of crude protein content according to the Kjeldahl method (ISO 20483: 2006);

- Ash: Cereals, legumes and by-products Determination of ash content by incineration (ISO 2171: 2007);

- Fat: Animal feed - Determination of fat content (MKS ISO 6492: 2012).

Statistical analysis of the results was performed by the method of variance analysis and Principal Component Analysis, using the JMP programme.

\section{RESULTS AND DISCUSSION}

\section{Protein content}

Oat grain is rich in high quality protein and therefore in the food industry a range of easily digestible products with high nutritional value, such as oat flakes, semolina, oat flour is produced (Antonova et al. 2000).

Among the constituent components of oats, protein concentration is often ranked as the highest because of its importance in the diet.

On average, for the two years, the variety Shampionka has the highest protein content $(14.80 \%)$, indicating that the grain is of high nutritional value (Tab. 1). There was a statistically significant difference between the examined genotypes. 


\section{Fat content}

Oat grains have more favourable fat composition than other cereals, since most triglycerides in fatty acids consist of oleic and linoleic acids. Oat grains are relatively rich in fat than other cereals and can vary from $3 \%$ to $11 \%$ by weight of different varieties, with lines containing up to $18 \%$ fat (Frey and Holland, 1999).

Among genotypes, the variance, in average for the test period is higher. The coefficient of variation (Tab. 1) is $19.37 \%$. Compared with the $\mathrm{CV} \%$ of other properties it becomes clear that only in fat the percent of variation is more severe.

On average, for the two years, the variety Krivogashtani has the highest fat content $(4.47 \%)$, indicating that the grain is of high nutritional value (Tab. 1). The results of our examinations match the examinations of Frey and Holland, 1999. There was a statistically significant difference between the analyzed genotypes.

\section{Ash content}

Oat grain in terms of dry matter, on average, contains $10-13 \%$ protein, $58-65 \%$ starch, 4.2 -
$5.5 \%$ fat, 11.6 - $14 \%$ raw fiber, 1.4 - $2 \%$ sugar and 3.2-3.8\% ash (Pospišil, 2010).

Regardless of the year of examination, the best genotype from the analyzed ones, with the highest ash content, showed the variety Baranja, and with the lowest variety Istra.

On average, for the research period, the variety Baranja have the highest ash content of $4.35 \%$ (Tab. 1). Along with her in the group $a$ is also the variety Shampionka with $4.30 \%$ ash. There is a statistically significant difference between genotypes.

\section{Cellulose content}

The cellulose is located in the fruit and seed layer in the amount of $10.0-11.50 \%$. Its quantity, above all, depends inversely on the size of the grains and the climatic conditions of the area in which it is grown (Василевски, 2004).

On average, for the period 2015-2016, all genotypes studied belonged to group a, ie all varieties and populations contain a high content of cellulose (Tab.1). Given that the property cellulose content is negatively correlated with the quality of oats, in plant selection, varieties with lower cellulose content are more important.

Table 1. Chemical composition of oats grown organically for the period 2015-2016.

\begin{tabular}{|c|c|c|c|c|}
\hline Varieties / Populations & $\begin{array}{c}\text { Protein content } \\
(\%)\end{array}$ & $\begin{array}{c}\text { Fat content } \\
(\%)\end{array}$ & $\begin{array}{c}\text { Ash content } \\
(\%)\end{array}$ & $\begin{array}{c}\text { Cellulose content } \\
(\%)\end{array}$ \\
\hline Krivogashtani & $13.75 \mathrm{ab}$ & $\mathbf{4 . 4 7} \mathbf{a}$ & $3.90 \mathrm{ab}$ & $14.95 \mathrm{a}$ \\
\hline Trebenishta & $13.25 \mathrm{~b}$ & $2.31 \mathrm{c}$ & $3.90 \mathrm{ab}$ & $17.55 \mathrm{a}$ \\
\hline Kuchevishte & $13.50 \mathrm{~b}$ & $3.65 \mathrm{ab}$ & $4.00 \mathrm{ab}$ & $21.15 \mathrm{a}$ \\
\hline Rajac & $13.65 \mathrm{~b}$ & $3.80 \mathrm{ab}$ & $3.75 \mathrm{~b}$ & $\mathbf{2 3 . 1 5} \mathbf{a}$ \\
\hline Slavuj & $13.75 \mathrm{ab}$ & $3.48 \mathrm{abc}$ & $3.95 \mathrm{ab}$ & $19.70 \mathrm{a}$ \\
\hline Lovken & $12.85 \mathrm{~b}$ & $3.53 \mathrm{abc}$ & $3.90 \mathrm{ab}$ & $21.85 \mathrm{a}$ \\
\hline Kupa & $12.95 \mathrm{~b}$ & $2.61 \mathrm{bc}$ & $3.75 \mathrm{~b}$ & $19.50 \mathrm{a}$ \\
\hline Baranja & $13.05 \mathrm{~b}$ & $2.81 \mathrm{bc}$ & $\mathbf{4 . 3 5} \mathbf{a}$ & $\mathbf{3 . 2 0} \mathrm{a}$ \\
\hline Eksplorer & $13.60 \mathrm{~b}$ & $2.64 \mathrm{bc}$ & $3.95 \mathrm{ab}$ & $19.85 \mathrm{a}$ \\
\hline Shampionka & $\mathbf{1 4 . 8 0} \mathrm{a}$ & $3.12 \mathrm{bc}$ & $\mathbf{4 . 3 0} \mathrm{a}$ & $17.80 \mathrm{a}$ \\
\hline Istra & $13.65 \mathrm{~b}$ & $3.23 \mathrm{abc}$ & $3.20 \mathrm{c}$ & $15.00 \mathrm{a}$ \\
\hline Mean & 13.53 & 3.23 & 3.90 & 19.46 \\
\hline LSD & 1.1 & 1.27 & 0.52 & 16.01 \\
\hline CV\% & 3.69 & 19.37 & 6.15 & 37.42 \\
\hline
\end{tabular}

LSD - Least Significant Difference; CV - Coefficient of variance 
The analysis of variance for the quality of oat grains in the period 2015-2016 is given in Table 2. Figures show that the properties protein, fat, and ash contents have relatively constant values over the years of research. For them, the conditions of the year had less influence than the genotype. Genotype strength was $65.06 \%, 67.06 \%$ and $72.04 \%$, respectively. The three features were also influenced by the interaction between genotype and the conditions of the year. Interaction ranges from $19.07 \%$ in ash content to $27.12 \%$ in fat content (Tab. 2). The property, cellulose content, unlike other properties, was strongly influenced by the conditions of the year, with the strength of the year factor being $69.12 \%$. Genotype also influences the content of cellulose $(\eta=21.64 \%)$, while the interaction between the factors year $x$ genotype is low $(\eta=9.24 \%)$.

Table 2. Analyzes of the variance of grain quality in oats for the period 2015-2016.

\begin{tabular}{|c|c|c|c|c|c|c|}
\hline \multirow{2}{*}{ Properties } & \multicolumn{6}{|c|}{ Source of variation } \\
\cline { 2 - 7 } & \multicolumn{2}{|c|}{ Genotype } & \multicolumn{2}{c|}{ Year } & \multicolumn{2}{c|}{ Interaction } \\
\cline { 2 - 7 } & MS & $\eta$ & MS & $\eta$ & MS & $\eta$ \\
\hline Protein content & $1.618^{* * * *}$ & 65.06 & $1.559^{* * *}$ & 12.54 & $0.557^{* * *}$ & 22.39 \\
\hline Fat content & $2.292^{* * * * * *}$ & 67.06 & $0.994^{* * * *}$ & 5.82 & $0.927^{* * * *}$ & 27.12 \\
\hline Ash content & $0.549^{* * *}$ & 72.40 & $0.549^{* * *}$ & 8.53 & $0.145^{* * *}$ & 19.07 \\
\hline Cellulose content & $45.570^{* * * *}$ & 21.64 & $759.584^{* * *}$ & 69.12 & $20.312^{* * * *}$ & 9.24 \\
\hline
\end{tabular}

MS - mean squares; $\boldsymbol{\eta}$ - effect of factor; ${ }^{* * *}$ - $\mathrm{P}<0,001$

In order to get a clearer picture of the general variation between the properties that determine the quality of oat grain, Principle Component Analysis, was performed. The results of the analysis are presented in Table 3 and Figure 1.

In 2015, two main components with eigenvalue higher than $1,00 \%$ were separated. The first main component accounts for $48.09 \%$ of the total variance, and the second with $27.51 \%$ of the total variance.

The cumulative percentage of both components was $75.60 \%$ of the total variation.
It is relatively high and the model can explain much of the variation in properties.

In 2016 there were also two main components with a eigenvalue higher than $1 \%$. The first main component accounts for $41.76 \%$ of total variance. The second component has a load limit value of 1.22 and accounts for $30.57 \%$ of the total variation of properties.

On the average, for the research period, two main components were also extracted and respectively for the two years, the cumulative percentage of the two components was $70.90 \%$ of the total variation (Tab. 3).

Table 3. Component vector analysis of the analyzed properties by years and average for the period 20152016.

\begin{tabular}{|c|c|c|c|c|c|c|c|c|c|}
\hline \multirow{2}{*}{ 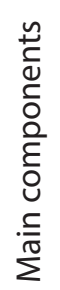 } & \multicolumn{3}{|c|}{2015 year } & \multicolumn{3}{|c|}{2016 year } & \multicolumn{3}{|c|}{ Mean for the period 2015-2016 } \\
\hline & 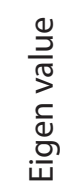 & 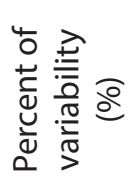 & 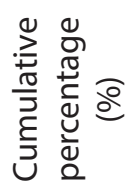 & $\begin{array}{l}\frac{0}{\frac{0}{5}} \\
\frac{\sqrt{5}}{2} \\
\frac{5}{4} \\
\frac{\pi}{4}\end{array}$ & 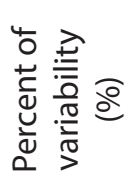 & 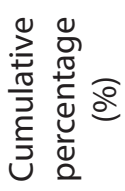 & 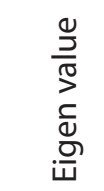 & 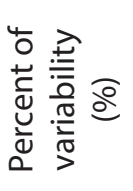 & 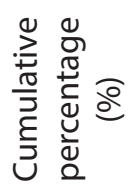 \\
\hline 1 & 1.92 & 48.09 & 48.09 & 1.67 & 41.76 & 41.76 & 1.61 & 40.21 & 40.21 \\
\hline 2 & 1.10 & 27.51 & 75.60 & 1.22 & 30.57 & 72.33 & 1.23 & 30.69 & 70.90 \\
\hline
\end{tabular}


The Figure 1 shows a grain quality projection of the analyzed oat varieties. The positive quadrant of the projection contains protein and fat content, indicating that there are varieties in the test group with high values. The vectors of these two indicators draw an acute angle, which proves the positive relationship between them. A positive relationship exists with the other two indicators characterizing the quality of the grain - ash content and cellulose content. Their vectors are in the negative quadrant of the plane and show that they are negatively related to protein and fat content and their value depends on the conditions of research. The genotypes Shampionka, Slavuj and Krivogashtani have the best combination of values according to the studied indicators. They are located in the positive part of the plane close to the vectors of protein and fat. Istra is also a variety with good quality indicators, but the location in the lower positive quadrant also indicates a dependence on environmental conditions. The greater number of varieties is located close to the cellulose vector, indicating that they have high values for this indicator.

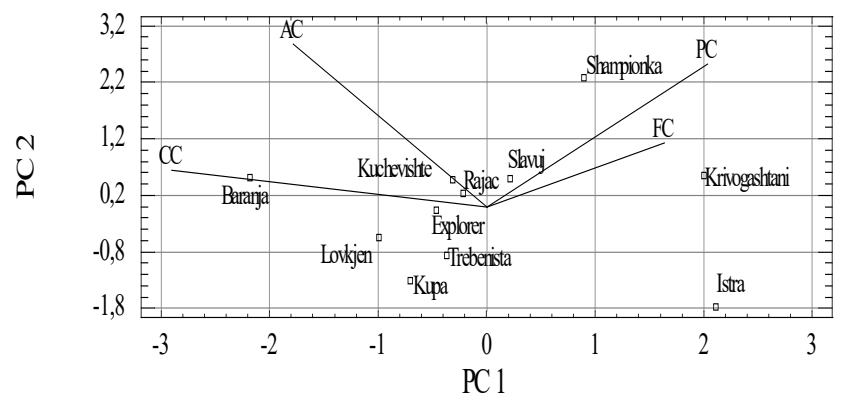

AC - Ash content; CC - Cellulose content; PC - Protein content; FC - Fat content

Figure 1. Projection of quality of oat varieties average for the test period of study.

\section{CONCLUDING REMARKS}

Based on two years of research and the results of the chemical composition of oats grown in organic production we can conclude that:

- On average, for the two years, the variety Shampionka has the highest protein content $(14.80 \%)$, indicating that the grain is of high nutritional value. There was a statistically significant difference between the examined genotypes.

- On average, for the period 2015-2016, the fat content of oats grain is highest in the genotype Krivogashtani (4.47).

- On average, for the research period, the variety Baranja has the highest ash content $-4.35 \%$. Along with it in the group a is also the variety Shampionka with $4.30 \%$. There is a statistically significant difference between genotypes.

- On average, for the period 2015-2016, all genotypes studied belong to group a, i.e., all varieties and populations contain high cellulose content. Given that the property cellulose content is negatively correlated with the quality of oats, in plant selection, varieties with lower cellulose content are more important.

- The properties content of protein, fat and ash are strongly influenced by the genotype while the cellulose content is strongly influenced by the year. 


\section{REFERENCES}

Antonova, N., Ivanov, P., Lozanov, I., Rachovska, G. (2000). Amino acid and protein analyses in the kernel of naked oat cultivars. U: $6^{\text {th }}$ International Oat Conference, Lincoln, p.8691.

Frey K. J., Colville D. C. (1986): Development rate and growth duration of oats in response to delayed sowing. Agronomy Journal. Vol. 78, p. 417-421.

Frey K. J. (1977): Protein of oats. Zeitschriftfur Pflanzenzüchtung, 78, 185-215

Frey, K.J., Holland, J.B., (1999). Nine cycles of recurrent selection for increased grain-oil content in oat. Crop Sci. 39, 1634-1641.

Galie Z., Bleidere M., Skrabule I., Vigovskis J. (2004): The first steps in variety testing for organic agriculture in Latvia: oats and potatoes. Proceedings of the First World Conference on Organic Seed. Challenges and Opportunities for Organic Agriculture and the Seed Industry, FAO Headquarters, Rome, 173-174, Italy.

Georgiev D., Daskalova S., Georgieva T. (2003): Protein composition of spring oat varieties, N. tr. of AU - Plovdiv, vol XLVIII, 113 118.

ISO 6865:2000, Animal feeding stuffs Determination of crude fibre content - Method with intermediate filtration..

ISO 20483: 2006, Cereals and legumes - Determination of nitrogen content and calculation of crude protein content according to the Kjeldahl method.

ISO 2171: 2007, Cereals, legumes and byproducts - Determination of ash content by incineration.

Lockeretz W, Shearer G, Kohl DH. (1981): Organic Farming in the Corn Belt. Science; 211: 540-547. Agro-Ecosystems.

MKS ISO 6492: 2012, Animal feed Determination of fat content.

Moudry J. (1992): Naked Oats. Methodologies for introducing research results into agricultural practice. Institute of Scientific and Technical Information for Agriculture, 36s.

Nikolić, J. A., Hristić, V., Krsmanovi ć . J . (1989). Some specifics of oat grains and wider use in the diet of humans and domestic animals. Improving the production of wheat and other small grains. Scientific meeting, 02.06.1988.
Small Grain Institute. Kragujevac.

Pospišil, A. (2010). Ratarstvo 1. dio. Zrinskid.d., Čakovec, 2010.

Savova T. (2007): Variation and correlations between selection traits in new wintering oat lines, International Scientific Conference - St. Zagora, Vol.1. Plant sciences, 250-25.

Saastamoinen, M., Hietaniemi, V., Pihlava, J-M., Eurola, M., Kontturi, M., Tuuri H., Niskanen, M., Kangas, A. (2004). B-glucan contents of groats of different oat cultivars in official variety, in organic cultivation, and in nitrogen fertilization trials in Finland, Agricultural and Food Science 13, 1-2: 68-79.

Spasova D. (2008): Variety specificity of oats in terms of organic and conventional production. Doctoral dissertation. University "St. Cyril and Methodius "- Skopje. Faculty of Agricultural Sciences and Food.

Spasojević B., Stanaćev S., Starcević Lj.,Marinković B. (1984): Special crops I (Introduction, cereals and legumes). University of Novi Sad, Faculty of Agriculture, OOUR Institute of Field and Vegetable Crops, Novi Sad.Sterbia Moudry. (2001). Yield formation and quality of naked oats (Avena nuda L.). $37^{\text {th }}$ Croatian symposium on agriculture, 262.

Vasilevski G. (2004). Grain and tuber crops, (University textbook). University " Ss. Cyril and Methodius " -Skopje, Faculty of Agricultural Sciences and Food-Skopje.Welch, R. (1995). The chemical composition of oats. In: Welch R.W. ed The Oat Crop. London: Chapman \& Hall, UK, 279-320.

Wood, P.J., (1986). Oat ß-glucan: Structure, location and properties. In: Webster, F.H. (ed) Oat: Chemistry and Technology. American Association of Cereal Chemists, St. Paul, Minnesota, 121-152.

Yeoh H. H. andWatson L. (1981): Systematic variation in aminoacid compositions of grass caryopses. Phytochemistry, 20, 1041-51.

Đekić v., Glamočlija đ., Milovanovič M., Staletič M. (2010): Influence of the year on grain yield and quality of Kragujevac varieties of winter wheat. Proceedings of the XXIV Conference of Agronomists, Veterinarians and Technologists, February 24-25, Belgrade, Vol. 16, No. 1-2, 43-50. 


\title{
КВАЛИТЕТНИ СВОЈСТВА НА ОВЕСОТ ОДГЛЕДУВАН ВО УСЛОВИ НА ОРГАНСКО ПРОИЗВОДСТВО
}

\author{
Драгица Спасова ${ }^{1 *}$, Дарина Валчева², Билјана Атанасова' , Адријана Буровска', \\ Душан Спасов' ${ }^{1}$ Мите Илиевски' \\ 'Земјоделски факултет, Универзитет „Гоче Делчев “' Штип, ул. Крсте Мисирков 10-А, 2000 Штип, \\ Република Северна Македонија \\ 2 Институт за земјоделие, 8400 Карнобат, Република Бугарија \\ *Контакт-автор: dragica.spasova@ugd.edu.mk
}

\section{Резиме}

Истражувањето е спроведено во 2015 и 2016 година, на 11 генотипови овес во услови на органскопроизводство.Три одиспитуваните генотипови седомашни популации:кривогаштани, требеништа и кучевиште. Останатите 8 се интродуирани сорти, и тоа: рајац, славуј и ловќен од Србија и купа, барања, експлорер, шампионка и истра од Хрватска.

Во просек, за двете години од испитувањето, сортата шампионка имаше најголема содржина на протеини (14,80\%), што укажува дека зрното има висока хранлива вредност. Постои статистички значајна разлика помеѓу испитуваните генотипови. Процентот на масти во овесот, органски одгледуван, во двете години на истражување е статистички различен кај испитуваните генотипови. Во просек, во двете години на истражување, содржината на масти се движеше од 2,31\% кај популацијата требеништа, до 4,47\% кај популацијата кривогаштани. Сортата барања е со најголема содржина на пепел во зрната (4,35\%) во просек, за периодот на истражување. Во истата група а е рангирана и сортата шампионка, со 4,30\% пепел. Помеѓу генотиповите постои статистички значајна разлика. За периодот 2015-2016 година сите испитани генотипови припаѓаат на групата а, односно сите сорти и популации содржат висока содржина на целулоза. Со оглед на тоа дека својството содржина на целулоза е во негативна корелација со квалитетот на овесот, во селекцијата на растенијата, позначајни се сортите со пониска содржина на целулоза. Анализата на варијанса за квалитетот на зрната од овес покажува дека содржината на протеини, маснотии и пепел е релативно константна во текот на годините на истражувањето. Условите во годините на истражување имаа послаб ефект од генотипот. Јачината на генотипот е $65,06 \%, 67,06 \%$ и 72,04\%, соодветно. Својствата, содржина на протеини, масти и пепел се под силно влијание на генотипот, додека содржината на целулоза е под силно влијание на влијанието на условите на годината на испитување.

Клучни зборови: вариетет, популација, протеини, масти, пепел, целулоза. 